\title{
Effect of Salt Stress on Medicinal Plants and its Amelioration by Plant Growth Promoting Microbes
}

\author{
Hemanta Kumar Mondal*and Harshpreet Kaur
}

Dept. of Microbiology, College of Basic Sciences \& Humanities, CCS HAU, Hisar, Haryana (125 004), India

\author{
Corresponding Author \\ Hemanta Kumar Mondal \\ e-mail: hkmsg07@gmail.com
}

\author{
Article History \\ Manuscript No. AR1772 \\ Received in $9^{\text {th }}$ January, 2017 \\ Received in revised form $29^{\text {th }}$ May, 2017 \\ Accepted in final form $7^{\text {th }}$ June, 2017
}

\begin{abstract}
Salt stress is widely recognized as one of the important abiotic stressors results the severe reduction of medicinal plants growth and its herb yield. It also critically reduces the production of medicinally important active chemical content in the plants. There are three main stages on the growth of medicinal plants where the high salinity stress severely affects the plant growth. Recent studies showed that there is reduction of herb yield around $60 \%$ and simultaneous active chemical content reduction of around $50 \%$ under the exposure of high salinity of $300 \mathrm{mM}$ of $\mathrm{NaCl}$ concentration. There are many reasons behind the reduction of growth of medicinal plants due to salt stress. There are also morphological, physiological and biochemical changes observed on the medicinal plants but there is still mystery exists whether any ultra-structural changes occur on the medicinal plants for salinity stress. The strategies employed in recent years to reduce the effect of high salinity stress on medicinal plant production mainly focused on a selection of salinity tolerant host genotypes. However, such efforts need high cost and inputs, there is an immediate urgency to build simple, low cost, sustainable and short term methods for salinity stress management. Hence the use of plant growth promoting microbes inhabiting rhizosphere, phyllosphere or endosphere might play a significant role in this aspect, if we exploit them as a multi-trait PGPR like stress-tolerant, PGPR activities, manipulation of signalling between both partners as plant and microbes with specific compatible solutes.
\end{abstract}

Keywords: Salinity stress, stress-tolerant, PGPR, medicinal plants, ultra-structural changes

\section{Introduction}

Medicinal plants frequently encounter unfavourable growth conditions due to salinization of soil and water. Salinity is one of the important abiotic environmental stressors that limit plant growth and development and plays a major role in determining the geographical distribution of medicinal plant species. In fact, almost $40 \%$ of the world's land surface is affected by salinity-related problems (Vriezen et al., 2007). According to an estimate, over 800 mha of land throughout the world are salt affected, either by salinity (397 mha) or the associated condition of sodicity (434 mha) (FAO, 2008). In India, according to recent survey around 6.74 mha of total land is occupied by salt affected soil and further categorized by three different types saline soils (1.71 mha), alkali soils (3.78 mha) and coastal saline soil (1.24 mha) (CSSRI, 2016). A saline soil is generally defined as one in which the electrical conductivity $(E C)$ of the saturation extract $\left(E C_{e}\right)$ in the root

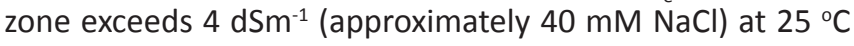
and has an exchangeable sodium of $15 \%$. It has been estimated that worldwide $20 \%$ of total cultivated and $33 \%$ of irrigated agricultural lands are afflicted by high salinity. Furthermore, the salinized areas are increasing at a rate of $10 \%$ annually for various reasons, including low precipitation, high surface evaporation, weathering of native rocks, irrigation with saline water, and poor cultural practices. It has been estimated that more than $50 \%$ of the arable land would be salinized by the year 2050 (Jamil et al., 2011). Tropical and sub-tropical countries like India, China, Egypt etc. are mainly blessed with a rich wealth of medicinal plants because of their high disease curing value. Medicinal plants are cultivated for different plant parts and their active constituents are used in many ways, especially for drugs. As antibiotics are very costly in developing countries people in these countries still mainly relies on herbal medicines for ailment of diseases (Abu-Irmaileh \& Afifi, 2000). Among the environmental unfavourable conditions, salinity is the most wide spread in the world. In order to meet the ever increasing demand of medicinal plants, for the indigenous systems of medicine as well as for the pharmaceutical industry, some medicinal plants need to be cultivated commercially, but the soil salinity and other forms of pollutions pose serious threats to plant production (Qureshi et al., 2005; Jaleel et al., 2007c, 2008a). The impact of salt stress has been correlated with some morphological and physiological 
traits like reduction in fresh and dry weight (Chartzoulakis and Klapaki, 2000). However, traditional and molecular breeding has been applied for saline tolerant medicinal plant varieties and showed significant tolerance in opposition to the negative effects of salinity. Although the effects of salt stress on traditional crops like wheat, barley, rice etc. have been studied widely, there is a lack of information in the case of medicinal plants.

Salt stressed soils are known to suppress the growth of plants (Paul, 2012). Plants in their natural environment are colonized both by endocellular and intracellular microorganisms (Gray and Smith, 2005). Rhizosphere microorganisms, particularly beneficial bacteria and fungi, can improve plant performance under stress environments and, consequently, enhance yield both directly and indirectly (Dimkpa et al., 2009). Some plant growth-promoting rhizobacteria (PGPR) may exert a direct stimulation on plant growth and development by providing plants with fixed nitrogen, phytohormones, iron that has been sequestered by bacterial siderophores, and soluble phosphate (Ahemad and Kibret, 2014). Others do this indirectly by protecting the plant against soil-borne diseases, most of which are caused by pathogenic fungi (Lutgtenberg and Kamilova, 2009). The problem of soil salinization is a scourge for agricultural productivity worldwide. Crops grown on saline soils suffer on an account of high osmotic stress, nutritional disorders and toxicities, poor soil physical conditions and reduced crop productivity (Srivastava and Kumar, 2015). The present review focuses on recent researches and advances in our understanding of salt stress on medicinal plants and the enhancement of plant productivity under salt stressed conditions through application of plant growth promoting microorganisms for alleviation of salt stress.

\section{Causes and Problems of Soil Salinization}

Salinization is one of the physicochemical process in which soil and water made saline due to presence of different salts. Soil salinity is an enormous problem for agriculture under irrigation. There are two main types of salinity, primary and secondary. Primary salinity occurs naturally in soil and water. Secondary salinity is salting which results from human activities, usually land development and agriculture. Common causes of secondary salinity are rising groundwater tables (from excessive irrigation) or the use of poor quality water or clearing vegetation and changes inland use (Bharti et al., 2013). In the hot and dry regions of the world the soils are frequently saline with low agricultural potential. In these areas most crops are grown under irrigation, and to exacerbate the problem, inadequate irrigation management leads to secondary salinization that affects $20 \%$ of irrigated land worldwide (Glick et al., 2007). Irrigated agriculture is a major human activity, which often leads to secondary salinization of land and water resources in arid and semi-arid conditions. Because of improper irrigation, anthropic salinization occurs in arid and semi-aridareas due to water logging. About $2 \%$ of the lands farmed by dry-land agriculture, and more than 45 million hectares of irrigated land (at least $20 \%$ of total irrigated acreage) have been already damaged by salt (Lauchli et al., 2008). Irrigation combined with poor drainage is themost serious salinity threat, because it represents losses of once productive agricultural land (Zhu, 2007). The irrigation water contains salts of calcium $\left(\mathrm{Ca}^{2+}\right)$, magnesium $\left(\mathrm{Mg}^{2+}\right)$, and sodium $\left(\mathrm{Na}^{+}\right)$. In arid and semi-arid lands, evapotranspiration plays a very important role in the pedogenesis of saline soils. When water evaporates, $\mathrm{Ca}^{2+}$ and $\mathrm{Mg}^{2+}$ often precipitate into carbonates, leaving $\mathrm{Na}^{+}$dominant in the soil (Serrano et al., 1999). Therefore, high concentrations of $\mathrm{Na}^{+}$in the soil solution may depress nutrient-ion activities and produce extreme ratios of $\mathrm{Na}^{+} / \mathrm{Ca}^{2+}$ or $\mathrm{Na}^{+} / \mathrm{K}^{+}$(Grattana \& Grieveb, 1999).

During the last century, physical, chemical and/or biological land degradation processes have resulted in serious consequences to global natural resources (e.g. compaction, inorganic/organic contamination, and diminished microbial activity/diversity). The area under the affected soils continues to increase each year due to introduction of irrigation in new areas (Patel et al., 2011). In India, Most of saline soil occurs in Indo-gangetic plane that covers the states of Punjab, Haryana, U.P., Bihar and some parts of Rajasthan. Arid tracts of Gujarat and Rajasthan and semi-arid tracts of Gujarat, Madhya Pradesh, Maharashtra, Karnataka and Andhra Pradesh are also largely affected by saline lands.

\section{Impact and Reason behind Salt Stress on Medicinal Plants}

Soil salinity is a problem of global concern. Plant growth in saline soils is suppressed by nonspecific osmotic effects, toxic solutes and sodicity. Agricultural crops exhibit a spectrum of responses under salt stress. Salinity not only decreases the agricultural production of most crops, but also, effects soil physicochemical properties, and ecological balance of the area (Srivastava and Kumar, 2015). The impacts of salinity include low agricultural productivity, low economic returns and soil erosions (Hu and Schmidhalter, 2002). Salinity effects are the results of complex interactions among morphological, physiological, and biochemical processes including seed germination, plant growth, and water and nutrient uptake (Akbarimoghaddam et al., 2011). Salinity affects almost all aspects of plant development including, germination, vegetative growth and reproductive development. Soil salinity imposes ion toxicity, osmotic stress, nutrient ( $N, C a$, $\mathrm{K}, \mathrm{P}, \mathrm{Fe}, \mathrm{Zn}$ ) deficiency and oxidative stress on plants, and thus limits water uptake from soil. Soil salinity significantly reduces plant phosphorus $(P)$ uptake because phosphate ions precipitate with $\mathrm{Ca}^{2+}$ ions (Bano and Fatima, 2009). Salinity also affects photosynthesis mainly through a reduction in leaf area, chlorophyll content and stomatal conductance, and to a lesser extent through a decrease in photosystem II efficiency (Netondo et al., 2004). Salinity adversely affects reproductive development by inhabiting microsporogenesis and stamen filament elongation, enhancing programed cell 
death in some tissue types, ovule abortion and senescence of fertilized embryos.

Salt stress can be categorized in two different stress effects e.g. short and long terms. In natural environment, salinity often associated with drought. Both drought and salinity impose osmotic stress, as a result of large concentrations of either salt or non-ionic solutes in the surrounding medium, with the resulting deficit of water. Osmotic stress, lowering of external water potential and reduction of water uptake by plants, similar to the situation under drought, all fall in the category of short term effects (Wang et al., 2003); The second effect, long term effect, is much slower process caused by salt accumulation in leaves, leading to salt toxicity in the plants and thus crops are not able to compartmentalize ions properly. The earliest response to salt stress in plants is a reduction in the rate of leaf surface expansion, followed by a cessation of expansion as the stress intensifies (Parida and Das, 2005). As salt composition varies, the plant growth differs accordingly. The plants that have evolved under conditions of low soil salinity and do not display salt tolerance, their yields move towards zero with the increase in salt concentrations. They are severely inhibited or even killed by 100-200 mM $\mathrm{NaCl}$ (Munns and Termaat, 1986). High salinity affects plants manly in two ways, when the salt concentrations is high in the soil, the capacity of roots to extract water is disturbed, and when concentrations of salts within the plant is high, then salt itself can be toxic to the plant, which results in an inhibition of many physiological and biochemical processes such as nutrient uptake and assimilation (Hasegawa et al., 2000; Munns, 2002; Munns et al., 1995; Munns and Tester, 2008). Altogether, these affects plant growth, development, survival and yield. Reduction in shoot growth due to salinity is commonly expressed by reduced leaf area and stunted shoots (Lauchli \& Epstein, 1990). The growth of leaves is inhibited due to salt stress and also as a consequence of inhibition by salt of symplastic xylem loading of $\mathrm{Ca}^{2+}$ in the root (Lauchli and Grattan, 2007). There is a formation of reactive oxygen species such as super-oxide, hydrogen peroxide, singlet oxygen and hydroxyl radicals, when there is ion excess into the cells. It further causes disruption in cellular homeostasis and also triggers the expression of genes involved in defence mechanisms (Timperio et al., 2008; Du et al., 2010). In addition, gene expression is also influenced by salt stress. Genes involved in the metabolic pathways of nitrogen reduction and fixation and methionine biosynthesis are significantly affected by salt stress (Ouyang et al., 2007). Jaleel et al. (2008) observed contrasting effect of $\mathrm{NaCl}$ treatment on medicinal plant Catharanthus roseus with significant accumulation of micro and macronutrients in plant cells but subsequent reduction of vegetative plant growth. In another study, Gengmao et al. (2014) reported that Salvia miltiorrhiza plant surviving at $75-100 \mathrm{mM} \mathrm{NaCl}$ concentrations was not affected by high salt exposure in morphological sense but the accumulation of plant dry matter was severely reduced.

\section{Effect of Salt Stress on Medicinal Plants}

According to recent reports, salt stress might occur on medicinal plants at three different physiological stages i.e. seed germination stage, seedling stage and maturity or reproductive stage.

\section{Effect on seed germination stage}

One of the most salt-sensitive growth stages which are severely inhibited with increasing salinity is seed germination stage (Sosa et al., 2005). This negative response of seed germination under salt stress was reported by many authors on Ocimum basilicum, Eruca sativa, Petroselinum hortense and Thymus maroccanus. Seed germination can be affected either by two ways. First is there may be decrease in the osmotic potential due to enough salt in the medium. It can be declined to such a point that it slows down the uptake of water necessary for mobilization of nutrient which is required for germination. The second is the salt constituents or ions may be toxic to the embryonic growth.

\section{Effect on Seedling Stage}

Seedling stage is one of the most vulnerable stages in the plants' life cycle. It was earlier observed that due to salt stress the seedling growth in Thymus maroccanus, basil (Ramin, 2005), chamomile and marjoram (Ali et al., 2007) was severely declined. Because of this salt stress, there is slow or less mobilization of reserve foods, suspending the cell division, enlarging and injuring hypocotyls. Osmotic stress, mainly specific ion toxicity and ionic imbalances occurred when there is an excess of soluble salts in the soil (Munns, 2003) which results death of plants (Rout and Shaw, 2005). Ozturk et al. (2004) observed that all seedlings of Melissa officinalis died at EC $6 \mathrm{dS} / \mathrm{m}$. Similar observation was also recorded for sage plants i.e. salinity level up to $3000 \mathrm{ppm}$ resulted in complete obliteration of sage plants (Hendawy and Khalid, 2005). It has been also reported in previous study that survival percentage in thyme was decreased significantly under salinity conditions (Ezz El-Dinet et al., 2009). The similar results were obtained on Majorana hortensis (Shalan et al., 2006) and spearmint (Al-Amier et al., 2007). The vegetative growth of five different medicinal plants namely Lepidium sativum L., Linum usitatissimum L., Nigella sativa L., Plantago ovate Forssk, and Trigonella foenum-graecum L. was significantly reduced when grown in pot house on different concentrations of salinity level viz. 10.0, 12.5 and $15.0 \mathrm{dS} / \mathrm{m}$ of $\mathrm{NaCl}$ (Muhammad and Hussain, 2010).

\section{Effect on Maturity Stage of Medicinal Plant and Reduction of Plant Yield}

Productivity of plant is severely affected by salt stress when salinity effect pronounced on plant maturity stage. Due to salt stress, detrimental and damaging effects on plants can be observed at the whole-plant level, as the death of plants 
and/or decrease in the productivity (Parida and Das, 2005). Noteworthy drop in the number of umbels, fruit yield/ plant and weight of 1000 seeds was observed in fennel, cumin and Ammi majus when salt concentrations increased (Nabizadeh, 2002; Ashraf et al., 2004; Abd El-Wahab, 2006). Similar reductions in seed yield and yield components per plant were obtained on milk thistle and Trachyspermum ammi (Ghavami and Ramin, 2008; Ashraf and Orooj, 2006). Contradictory reports have been found relating to the response of medicinal plants in terms of essential oil production to salt stress. Essential oil yield decreased under salt stress in Trachyspermum ammi (Ashraf and Orooj, 2006). In several medicinal plants e.g., Mentha piperita (Tabatabaie and Nazari, 2007), Thymus maroccanus (Belaqziz et al., 2009), basil (Said-Al Ahl and Omer, 2011) and apple mint (Aziz et al., 2008) similar results have been documented. It has also been shown that reactions to salt stress might be responsible for the increase or decrease in the content of relevant natural products in some Indian medicinal plants but exact reason is still unknown (Bharati et al., 2013). The concentration of artemisinin, an antimalarial compound decreased significantly in Artemisia annua plants when artificially treated with higher concentration of $\mathrm{NaCl}$ i.e., $160 \mathrm{mM}$ (Qureshi et al., 2005). Ajmalicine content in Catharanthus roseus was significantly reduced when plants grown on $100 \mathrm{mM} \mathrm{NaCl}$ concentration under pot house condition (Jaleel et al., 2008). According to recent report, in plant Bacopa monnieri the herb yield was reduced up to $60 \%$ and active chemical bacoside-A content reduced around $50 \%$ when plants were exposed to salinity in the field with concentration of $4 \mathrm{~g} \mathrm{NaCl} / \mathrm{kg}$ soil (Bharti et al., 2013). In Mentha arvensis, the biomass yield reduced up to $53 \%$ in $300 \mathrm{mM} \mathrm{NaCl}$ and $67 \%$ in $500 \mathrm{mM}$ of $\mathrm{NaCl}$ with significant reduction in oil content (Bharti et al., 2014).

\section{Morphological and Physiological Changes by Salt Stress}

Morphological features like number of leaves, leaf area, and leaf biomass have been reduced under salt stress in a number of medicinal plants. In Mentha piperita var. officinalis and Lipia citriodora var. verbena, there was significant diminution in number of leaves, leaf area and leaf biomass under salt stress (Tabatabaie and Nazari, 2007). Catharanthus plants act as an absorber of $\mathrm{Na}^{+}$and may be incapable of coping with it, leading to the leaves eventually suffering from the toxic effects and resulting in reduced leaf growth (Jaleel et al., 2008b). Similar decreases in growth parameters under salt stress were found in Withania somnifera (Jaleel et al., 2008a). Negative effects of salt stress have been observed in Majorana hortensis (Shalan et al., 2006), peppermint (Aziz et al., 2008), geranium (Leithy et al., 2009), Thymus vulgaris (Najafian et al., 2009), sage (Ben Taarit et al., 2009), and Mentha pulegium (Queslati et al., 2010). Due to abiotic stress from salt, the plant tries to cope with the situation by decreasing its leaf area, hence, conserving energy. Similarly when Satureja hortensis plants grown in different levels of $\mathrm{NaCl}$, the leaf area, leaf and stem fresh weight, as well as dry weight of leaves, stems and roots were decreased (Najafi et al., 2010). In another study, the growth of root was declined in Melissa officinalis when irrigated with each increase in irrigation water salinity (Ozturk et al., 2004). Salt stress can affect the all plants by disrupting their physiological mechanisms such as decreasing photosynthetic efficiency, gas exchange, membrane disruption, water status, etc. Increasing salinity causes a reduction in chlorophyll content (Sheng et al., 2008) due to suppression of specific enzymes that are responsible for the synthesis of photosynthetic pigments (Murkute et al., 2006). A reduction in the uptake of minerals (e.g. Mg) needed for chlorophyll biosynthesis also reduces the chlorophyll concentration in the leaf (El-Desouky and Atawia, 1998). In $\mathrm{NaCl}$ treated Artemisia annua plants, oxidative stress induced due to a decreased stomatal conductance in response to the osmotic imbalance and reduced leaf-water potential (Qureshi et al., 2005). Chlorophyll content in Catharanthus roseus was significantly reduced when plants grown on $100 \mathrm{mM} \mathrm{NaCl}$ concentration under pot house condition (Jaleel et al., 2008).

\section{Biochemical Changes on Plant}

Major biochemical changes occur in all plants including medicinal plants by accumulating a number of osmoregulatory nitrogen-containing compounds in Plant cells exposed to saline stress. The most common of these include amino acids, amide and proteins; also quaternary ammonium compounds (betaines) and polyamines (Rabie and Almadini, 2005). These compounds are generally present in low concentrations when the plant is not under salt stress (Feng et al., 2002). The specific nitrogen-containing compounds that accumulate in saline environments vary with plant species (Rabie and Almadini, 2005). Recently reported on proline concentration in the leaf of Echium amoenum was increased with increasing salinity, particularly at the highest external salt level and showed the positive role of proline in the salt tolerance of this medicinal plant (Ramezani et al., 2011). Osmoregulation allows cells to maintain turgor and turgor-dependent processes including cellular expansion and growth, stomatal opening and photosynthesis, while keeping a gradient of water potential favourable to water entering the plant.

\section{Ultra-structural Changes on Plants}

Salinity is reported to bring about drastic ultra-structural changes in plants (Yamane et al., 2004; Mahmoodzadeh, 2008; Evelin et al., 2009). Salt stress caused an increase in membrane surface and quantity of vesicles in root cells of Sorghum (Evelin et al., 2009). The plant cell membranes are generally considered as primary sites of salt injury. Membrane destabilization is frequently attributed to lipid peroxidation, which can be initiated by activated oxygen species such as $\mathrm{O}^{-2}, \mathrm{OH}^{-}$or ${ }_{1} \mathrm{O}^{2}$ or by the action of lipoxygenase. Thickened cell wall, increased frequency of plasmodesmata and vacuolization of cytoplasm were reported in the shoot 
apical meristem of canola (Mahmoodzadeh, 2008) due to salt stress. Yamane et al. (2004) observed disruptions in thyllakoid and thyllakoid membrane, while Sun et al. (2004) reported induction of ovule abortion in Arabidopsis thaliana due to dissipation of mitochondrial membrane potential (Hauser et al., 2006). Subsequently, cells in the gametophyte accumulate reactive oxygen species which gradually leads to programmed cell death (Hauser et al., 2006). The aborting gametophytes develop concentric rings of endoplasmic reticulum (autophagic bodies) surrounding chloroplasts, mitochondria, micro-bodies and cytoplasm. The cytoplasmic contents and organelles were invaginated into the vacuole. However, the formation of autophagic bodies and vacuoles is not found in every aborting ovule suggesting that these events are not related to programmed cell death (Hauser et al., 2006). Still date no such ultra-structural changes on medicinal plants reported or studied in details.

\section{Plant Growth Promoting Microbes (PGPM) on Mitigating Salt Stress}

The use of plant growth promoting microbes plays an important role on improvement of agricultural crop production including medicinal plant yield. It acts as a supplement to improve the growth and yield of several agricultural, horticultural and also for medicinal plants (Murthy et al., 1998; Lugtenberg \& Kamilova, 2009). This approach might constitute two broad different ways first accomplished through all kinds of microbes inhabiting rhizosphere, rhizoplane, phyllosphere and endophytes. Second approach strongly focussed on the exploitation of the plant growth promoting rhizobacteria or PGPR because it possesses more direct effect and wider cross talk with host as plant than others (Figure 1). Hence, the

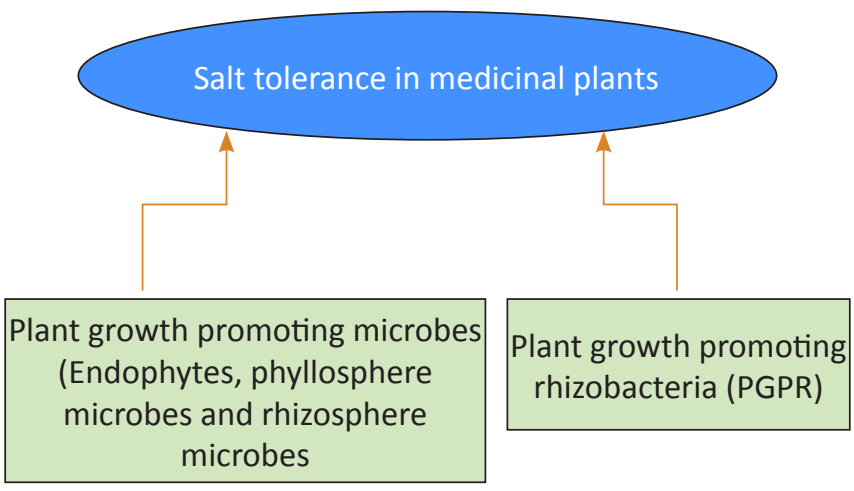

Figure 1: Improvement of salt tolerance in medicinal plants by two different approaches

opportunity and scope for success on manipulating the PGPR are far greater than others. The role of microorganisms in plant growth promotion, nutrient management and disease control is well known and well established. The association between plant-beneficial microbes (including PGPR) and their host plant(s) is thought to be ancient (Lambers et al., 2009) and has probably been shaped by co-evolutionary processes, which suggests that the microbial partners could have significant effects on host physiology (Bharti et al., 2013). These beneficial microorganisms colonize the rhizosphere/endorhizosphere, phyllosphere or inhabit inside the plants and promote growth of the plants through various direct and indirect mechanisms (Lugtenberg and Kamilova, 2009).

There are profound literature based on the mechanism by which they aid plant growth and productivity. Still the exact mechanism in this regard is quite puzzling and intriguing. It showed that they can minimize the harsh effects of external stress factors, and protect plants from soil-borne pests and diseases by producing different antibiotics, hydrolytic enzymes, capable of producing phytostimulators etc (Kachhap et al., 2015). Plant growth and productivity is highly affected by these interactions. Different types of microorganisms such as bacteria, fungi including mycorrhiza, protozoa, and algae coexist among them. Beneficial microbes including rhizospheric bacteria, plant growth promoting rhizobacteria (PGPR), endophytes (arbuscular mycorrhiza, bacteria and actinomycetes) were successfully studied for the ameliorating effects on soil salinity in medicinal plants. Plant growthpromoting microbes found in the rhizosphere of various plants grown in different soils and climatic conditions can provide a wide spectrum of benefits to plants (Mayak et al., 2004). The growth promotion of PGPR will be discussed separately. It has been demonstrated that inoculations with AM (arbuscular mycorrhizal) fungi improves plant growth under salt stress as well as acidic stress (Evelin et al., 2009; Mondal et al., 2016). Several studies investigating the role of AMF in protection against salt stress have demonstrated that the symbiosis often results in increased nutrient uptake, accumulation of an osmoregulator, an increase in photosynthetic rate and water-use efficiency, suggesting that salt-stress alleviation by AMF results from a combination of nutritional, biochemical and physiological effects. The inoculation of AM fungi Glomus intraradices in medicinal plants Ocimum basilicum significantly increases potassium uptake in plants and on the other side reduced the uptake of $\mathrm{Na}^{+}$and $\mathrm{Cl}^{-}$ions when plants grown indigenously on soils with $7.56 \mathrm{dS} / \mathrm{m}$ of salinity (Zuccarini and Okurowska, 2008). The inoculation with diazotrophic endophytic bacteria Achromobacter xylosoxidans in medicinal plant Catharathus roseus resulted significant reduction of the level of stress hormone ethylene when plants grown on highly salt affected coastal saline soil of Tamil Nadu, India (Karthikeyan et al., 2012). Inoculation of Glycyrrhiza glabra with AM fungi Glomus aggregatum along with Trichoderma harzianum and Bacillus coagulans enhanced significantly its growth, plant biomass yield, nutrition and secondary metabolites (Selvaraj and Sumithra, 2011). Plant growth promotion in medicinal plants through mediated by phyllosphere microbes is yet to be investigated and there is no literature found in this regard.

\section{Alleviation of Salinity stress in Plants by Plant Growth Promoting Rhizobacteria (PGPR)}

Nowadays, several strategies have been developed in order 
to decrease the toxic effects caused by high salinity on plant growth, including recently the use of plant growth-promoting rhizobacteria (PGPR) (Dimkpa et al., 2009; Srivastava and Kumar, 2015). Previous studies suggest that utilization of PGPR has become a promising alternative to alleviate plant stress caused by salinity and the role of microbes in the management of biotic and abiotic stresses is gaining importance. The subject of PGPR elicited tolerance to abiotic stresses has been reviewed recently (Srivastava and Kumar, 2015; Mondal et al., 2017). To be an efficient PGPR, bacteria must be able to colonize roots because bacteria need to establish itself in the rhizosphere at population densities sufficient to produce beneficial effects (Lugtenberg \& Kamilova, 2009; Kachhap et al., 2015). They have been known to stimulate and enhance plant growth directly as they can improve and mobilize the supply of nutrients, such as nitrogen (Dobbelaere et al., 2003) and phosphorous and make them available for plant uptake or by production of phytohormones and growth regulators as well as indirectly by the suppression of pathogens by resisting, inhibiting through mechanisms of antibiosis, iron sequestration by siderophores, secreting cell wall degrading enzymes like chitinase, cellulase etc and improving soil structure by production of polysachharide (Kachhap et al., 2015). It was also reported that the higher levels of the catalase and ascorbate peroxidase enzymes in the rhizobacteria inoculated plants can be associated with the enhanced tolerance towards salinity stress (Bharti et al., 2013). In medicinal plants it was previously reported that PGPR are able to enhance the rate of seed germination, seedling emergence, root and shoot growth, nutrient uptake, seed weight, yield, protecting plants from adverse effects of external stress factors and soil-borne diseases is documented for many plant species (Dobbelaere et al., 2003; Egamberdieva et al., 2010; Egamberdieva et al., 2012). The bacterial genera such as Agrobacterium, Arthrobacter, Azotobacter, Azospirillum, Bacillus, Flavobacterium, Pseudomonas and Serratia belong to PGPR. One of the recent potential approaches to mitigate the salt stress problem is the use of plant growth-promoting rhizobacteria (PGPR). Many Gram positive and Gram negative PGPR have been reported to colonize the plant rhizosphere and boosted plant growth by various direct and indirect mechanisms (Glick, 1995).

Investigations on the interaction of PGPR with other microbes and their effect on the physiological response of crop plants under different salt effected regimes are still at an incipient stage (Singh et al., 2011; Srivastava and Kumar, 2015). Rhizosphere microbes appeared to use carbon rich root exudates in the forms of sugar and acids for growth and production of secondary metabolites including phytohormones, and it will stimulate root growth, development and root surface area for enhancing nutrients uptake (Compant et al., 2005; Adesemoye et al., 2008). PGPR also help in enhance plant resistance to adverse environmental stresses such as salinity, drought, water-logging and heavy metals (Glick et al., 2007; Mondal et al., 2017). These PGPR (e.g., Rhizobium, Azospirillum,
Pseudomonas, Flavobacterium, Arthrobacter and Bacillus) utilize osmoregulation, oligotrophic, endogenous metabolism, resistance to starvation, and efficient metabolic processes to adapt under dry and saline environments (Lugtenberg et al., 2001; Egamberdieva and Islam, 2008). This group of bacteria, with a physiological adaptation and genetic potential for increased tolerance to drought, increasing salt concentration, and high temperatures, could improve plant production in degraded sites. Recent studies on the effect of PGPR for mitigation of salinity stress on medicinal plants showed the potential aspect for future. The salt tolerant, IAA producing bacterial strains Pseudomonas aureantiaca TSAU22 and $P$. extremorientalis TSAU20 were able to alleviate salt stress in medicinal plant Sylebum marianum grown under saline conditions (Egamberdieva et al., 2013). Egamberdieva (2013) have observed that the inoculation of pepper with bacterial strains of $P$. putida TSAU1, $P$. extremorientalis TSAU6, $P$. chlororaphis TSAU13 and $P$. aureantiaca TSAU22 significantly increased the shoot, root length and dry weight of whole plants grown in saline arid soil. P. chlororaphis TSAU13 strain were found the most effective strain for growth stimulation, where the shoot length increased upto $27 \%$, root length $21 \%$ and dry weight of plant upto $20 \%$. There are also existing evidences showed that the correlation between the ability of phytohormone production on PGPR and suppressing the negative effects of salt stress on medicinal plants and enhance their productivity. Galega officinalis L. commonly known as goat's rue, used for medicinal purposes (Atanasov, 1994; Atanasov \& Spasov, 2000; Pundarikakshudu et al., 2001), is one of the cultivated medicinal salt sensitive plants. Coinoculation of salt-stressed goat's rue with Rhizobium galegae and Pseudomonas extremorientalis significantly improved the root and shoot growth, nodulation and $\mathrm{N}$ content of plant roots grown in potting soils (Egambardieva et al., unpublished data). The salt tolerant, IAA producing bacterial strains $P$. aureantiaca TSAU22 and $P$. extremorientalis TSAU20 were able to alleviate salt stress in medicinal plant Sylebum marianum grown under saline conditions (Egamberdieva et al., 2013). Inoculations with selected PGPR and other microbes could serve as the potential tool for alleviating salinity stress in salt sensitive crops. Therefore, an extensive investigation is needed in this area, and the use of PGPR and other symbiotic microorganisms, can be useful in developing strategies to facilitate sustainable agriculture in saline soils. A novel PGPR bacteria Exiguobacterium oxidotolerans STR36 inoculated Bacopa monnieri plants recorded 109 and $138 \%$ higher herb yield (Table 1.) and also recorded 36 and $76 \%$ higher active chemical bacoside-A content under severe salinity stress in field condition with salinity level of $4 \mathrm{~g} \mathrm{NaCl} / \mathrm{kg}$ in soil (Bharti et al., 2013). At salinity levels of 100 and $300 \mathrm{mM} \mathrm{NaCl}$, Halomonas desiderata inoculated Mentha arvensis plants recorded the highest herb yield, whereas at $500 \mathrm{mM} \mathrm{NaCl}$, the plants inoculated with $E$. oxidotolerans yielded maximum herb (Bharti et al., 2014). The recent studies on the effect of PGPR on medicinal plant yield are summarised in Table 1. 
Table 1: Role of PGPR on medicinal plants in amelioration of salt stress

\begin{tabular}{|c|c|c|c|}
\hline PGPR & Medicinal plants & Effect & References \\
\hline Bacillus megaterium & Catharanthus roseus & $\begin{array}{l}\text { Plant growth, enhanced secondary } \\
\text { metabolites content }\end{array}$ & Karthikeyanet al., 2009 \\
\hline Pseudomonas extremorientalis & Silybum marianum & Increased biomass & Egamberdievaet al., 2013 \\
\hline Azotobacter chrooccocum & Catharanthus roseus & Increased biomass & Karthikeyanet al., 2009 \\
\hline Pseudomonas putida & Ocimum basilicum & $\begin{array}{l}\text { Increased biomass and secondary } \\
\text { metabolites content }\end{array}$ & Golpayegani and Tilebeni, 2011 \\
\hline Bacillus lentus & Ocimum basilicum & Increased biomass & Golpayegani and Tilebeni, 2011 \\
\hline Exiguobacterium oxidotolerans & Bacopa monnieri & $\begin{array}{l}\text { Increased herb yield and bacoside- } \\
\text { A content }\end{array}$ & Bharti et al., 2013 \\
\hline Bacillus pumilus & Bacopa monnieri & Plant weight, bacoside-A content & Bharti et al., 2013 \\
\hline Bacillus coagulans & Glycyrrhiza glabra & $\begin{array}{l}\text { Increased biomass and secondary } \\
\text { metabolites content }\end{array}$ & Selvaraj and Sumithra, 2011 \\
\hline $\begin{array}{l}\text { Azospirillum brasilense and } \\
\text { Pseudomonas fluorescens }\end{array}$ & Catharanthus roseus & $\begin{array}{l}\text { Increased biomass and ajmalicine } \\
\text { content }\end{array}$ & Karthikeyanet al., 2009 \\
\hline Halomonas desiderata & Mentha arvensis & Increased herb yield & Bharti et al., 2014 \\
\hline Exiguobacterium oxidotolerans & Mentha arvensis & Increased herb yield & Bharti et al., 2014 \\
\hline
\end{tabular}

\section{Conclusion}

The growing menace of salinity stress on medicinal plant yield is still increasing on steady state due to the increment of soil salinization rate day by day. There are a few approaches like development of salinity stress-tolerant plant genotypes though it is cost effective and takes long time to develop such genotypes. Hence, the use of plant growth promoting microbes gives light to construct a sustainable approach to mitigate high salinity stress on medicinal plants. In near future, further exploitation of beneficial microbes and manipulation of interaction of plant microbiome sphere give better hope for this strategy.

\section{References}

Abd El-Wahab, M.A., 2006. The efficiency of using saline and fresh water irrigation as alternating methods of irrigation on the productivity of Foeniculum vulgare Mill sub sp. vulgare var. vulgare under North Sinai conditions. Research journal of agriculture and biological sciences 2, 571-577.

Abu-Irmaileh, B.E., Afifi, F.U., 2000. Treatment with medicinal plants in Jordan. Dirasat, Medical and Biological Sciences 27, 53-74

Adesemoye, A.O., Obini, M., Ugoji, E.O., 2008. Comparison of plant growth promotion with Pseudomonas aeruginosa and Bacillus subtilis in three vegetables. Brazilian Journal of Microbiology 39, 423-426.

Ahemad, M., Kibret, M., 2014. Mechanisms and applications of plant growth promoting rhizobacteria: Current perspective. Journal of King Saud University-Science 26, 1-20.
Akbarimoghaddam, H., Galavi, M., Ghanbari, A., Panjehkeh, N., 2011. Salinity effects on seed germination and seedling growth of bread wheat cultivars. Trakia Journal of Sciences 9, 43-50.

Al-Amier, H., Craker, L.E., 2007. In-vitro selection for stress tolerant spearmint. Reprinted, Issues in new crops and new uses. Janick, J., Whipkey, A. (Eds.). ASHS Press, Alexandria, VA. 306-10.

Ali, R.M, Abbas, H.M., Kamal, R.K., 2007. The effects of treatment with polyamines on dry matter, oil and flavonoid contents in salinity stressed chamomile and sweet marjoram. Plant Soil and Environment 53, 529-543.

Ashraf, M., Mukhtar, N., Rehman, S., Rha, E.S., 2004. Saltinduced changes in photosynthetic activity and growth in a potential medicinal plant Bishop's weed (Ammi majus L.). Photosynthetica 442, 543-50.

Ashraf, M., Orooj, A., 2006. Salt stress effects on growth, ion accumulation and seed oil concentration in an arid zone traditional medicinal plant ajwain (Trachyspermum ammi L. Sprague). Journal of Arid Environments 64, 209-20.

Atanasov, A.T., 1994. Effect of the water extract of Galega officinalis L. on human platelet aggregation in vitro. Phytotherapy Research 8, 314-316.

Atanasov, A.T., Spasov, V., 2000. Inhibiting and disaggregating effect of gel filtered Galega officinalis L. herbal extract on platelet aggregation. Journal of Ethnopharmacology 69, 235-240.

Aziz, E.E., Al-Amier, H., Craker, L.E., 2008. Influence of salt stress on growth and essential oil production in 
peppermint, pennyroyal, and apple mint. Journal of Herbs, Spices \& Medicinal Plants 14, 77-87.

Bano, A., Fatima, M., 2009. Salt tolerance in Zea mays (L.) following inoculation with Rhizobium and Pseudomonas. Biology and Fertility of Soils 45, 405-413.

Belaqziz, R., Romane, A., Abbad, A., 2009. Salt stress effects on germination, growth and essential oil content of an endemic thyme species in Morocco (Thymus maroccanus Ball). Journal of Applied Science and Research 5(7), 858-63.

Ben Taarit, M.K., Msaada, K., Hosni, K.M., Hammami, M., Kchouk, E., Marzouk, B., 2009. Plant growth, essential oil yield and composition of sage (Salvia officinalis L.) fruits cultivated under salt stress conditions. Industrial Crops and Products 30, 333-7.

Berg, G., Krechel, A., Ditz, M., Faupel, A., Ulrich, A., Hallmann, J., 2005.Comparison of endophytic and ectophytic potato-associated bacterial communities and their antagonistic activity against plant pathogenic fungi.FEMS Microbiology Ecology 51, 215-229.

Bharti, N., Barnawal, D., Awasthi, A., Yadav, A., Kalra, A., 2014. Plant growth promoting rhizobacteria alleviate salinity induced negative effects on growth, oil content and physiological status in Menthaarvensis. Acta Physiologiae Plantarum 36, 45-60.

Bharti, N., Yadav, D., Barnawal, D., Maji, D., Kalra, A., 2013. Exiguobacterium oxidotolerans, a halotolerant plant growth promoting rhizobacteria, improves yield and content of secondary metabolites in Bacopa monnieri (L.) Pennell under primary and secondary salt stress.World Journal of Microbiology and Biotechnology 29, 379-387

Chartzoulakis, K., Klapaki, G., 2000. Response of two greenhouse pepper hybrids to $\mathrm{NaCl}$ salinity during different growth stages. Scientia Horticulturae 86, 247-260.

Compant, S., Reiter, B., Sessitsch, A., Nowak, J., Clément, C., Barka, E.A., 2005.Use of plant growth-promoting bacteria for biocontrol of plant diseases, Principles, mechanisms of action, and future prospects. Applied and Environmental Microbiology 71, 4951-4959.

CSSRI, 2008. Extent and distribution of salt affected soils in India. Karnal, India, CSSRI of Indian Council of Agricultural Research. Available from http://www.cssri. org/index.php?option=com_content\&view=article\&id $=122$ \&ltemid $=126$.

Dimkpa, C., Weinand, T., Ash, F., 2009. Plant-rhizobacteria interactions alleviate abiotic stress conditions. Plant Cell and Environment 32, 1682-1694.

Dobbelaere, S., Croonenborghs, A., Thys, A., Ptacek, D., Vanderleyden, J., Dutto, P., Labandera-Gonzalez, C., Caballero-Mellado, J., Anguirre, J.F., Kapulnik, Y., Brener, S., Burdman, S., Kadouri, D., Sarig, S., Okon, Y., 2003. Response of agronomically important crops to inoculation with Azospirillum. Australian Journal of Plant
Physiology 28, 871-879.

Du, C.X., Fan, H.F., Guo, S.R., Tezuka, T., Li, J., 2010. Proteomic analysis of cucumber seedling roots subjected to salt stress. Phytochemistry 71, 1450-1459

Egamberdieva, D., 2012. Pseudomonas chlororaphis, A salttolerant bacterial inoculant for plant growth stimulation under saline soil conditions. Acta Physiologiae Plantarum 34, 751-756.

Egamberdieva, D., Berg, G., Lindstrom, K., Rasanen, L. A., 2013. Alleviation of salt stress of symbiotic Galega officinalis L. (goat's rue) by co-inoculation of Rhizobium with rootcolonizing Pseudomonas. Plant Soil 369, 453-465.

Egamberdieva, D., Islam, K.R., 2008. Salt tolerant rhizobacteria, Plant growth promoting traits and physiological characterization within ecologically stressed environment. In: Ahmad, I., Pichtel, J. and Hayat, S.H. (Eds.), Plant-Bacteria Interactions, Strategies and Techniques to Promote Plant Growth, Wiley-VCH VerlagGmb-H and Co., Weinheim, Germany, 257-281.

Egamberdieva, D., Jabborova, D., Mamadalieva, N., 2013. Salt-tolerant Pseudomonas extremorientalis able to stimulate growth of Silybum marianum under salt stress condition.Medicinal and Aromatic Plant Science and Biotechnology7 (Special Issue), in press.

Egamberdieva, D., Kucharova, Z., Davranov, K., Berg, G., Makarova, N., Azarova, T., Chebotar, V., Tikhonovich, I., Kamilova, F., Validov, S., Lugtenberg, B., 2010.Bacteria able to control foot and root rot and to promote growth of cucumber in salinated soils. Biology and Fertility of Soils 47, 197-205.

El-Desouky, S.A., Atawia, A.A.R., 1998. Growth perfomance of citrus rootstocks under saline conditions. Alexandria Journal of Agricultural Research 43, 231-254.

Evelin, H, Kapoor, R, Giri, B., 2009. Arbuscular mycorrhizal fungi in alleviation of salt stress, a review. Annals of Botany 104, 1263-1280.

Ezz El-Din, A.A., Aziz, E.E., Hendawy, S.F., Omer, E.A., 2009. Response of Thymus vulgaris $L$. to salt stress and alar (B9) in newly reclaimed soil. Journal of Applied Sciences Research 5, 2165-2170.

FAO, 2008. FAO land and plant nutrition management service. Rome, FAO of UN. Available fromhttp://www.fao.org/ ag/agl/agll/spush.

Feng, G., Zhang, F.S,. Li, X.I., Tian, C.Y., Tang, C., Rengel, Z., 2002. Improved tolerance of maize plants to salt stress by arbuscularmycorrhiza is related to higher accumulation of soluble sugars in roots. Mycorrhiza 12, 185-190.

Gengmao, Z., Quanmei, S., Yu, H., Shihui, L., Changhai, W., 2014. The physiological and biochemical responses of a medicinal plant (Salvia miltiorrhiza L.) to stress caused by various concentrations of $\mathrm{NaCl}$. Plos One 9, 1-6

Ghavami, A., Ramin, A., 2008. Grain yield and active substances of milk thistle as affected by soil salinity. Communications in Soil Science and Plant Analysis 39, 
2608-2618.

Glick, B.R., 1995. The enhancement of plant growth by freeliving bacteria. Canadian Journalof Microbiology 41, 109-114.

Glick, B.R., Cheng, Z., Czarny, J., Duan, J., 2007. Promotion of plant growth by ACC deaminase-producing soil bacteria. European Journal of Plant Pathology 119, 329-339.

Golpayegani, A., Tilebeni, H.G., 2011. Effect of Biological Fertilizers on Biochemical and Physiological Parameters of Basil (Ociumum basilicm L.) Medicine Plant. AmericanEurasian Journal of Agricultural \& Environmental Sciences 11, 411-416.

Grattana, S.R., Grieveb, C.M., 1999. Salinity-mineral nutrient relations in horticultural crops.Scientia Horticulturae 78, 127-157.

Gray, E.J., Smith, D.L., 2005. Intracellular and extracellular PGPR, commonalities and distinctions in the plantbacterium signalling processes. Soil Biology and Biochemistry 37, 395-412.

Hasegawa, P. M., Bressan, R.A., Zhu, J.K., Bohnert, H.J., 2000. Plant cellular and molecular responses to high salinity. Annual Review of Plant Physiology and Plant Molecular Biology 51, 463-499.

Hauser, B.A., Oppenheimer, K.S.D.G., Sage, T.L., 2006. Changes in mitochondrial membrane potential and accumulation of reactive oxygen species precede ultra-structural changes during ovule abortion. Planta 223, 492-499.

Hendawy, S.F., Khalid, K., 2005. Response of sage (Salvia officinalis L.) plants to zinc application under different salinity levels. Journal of Applied Sciences and Research 1, 147-55.

Hu, Y., Schmidhalter, U., 2002. Limitation of salt stress to plant growth.In, Hock, B., Elstner, C.F. (Eds.), Plant Toxicology. Marcel Dekker Inc., New York, 91-224.

Jaleel, C.A., Gopi, R., Sankar, B., Manivannan, P., Kishore K. A., Sridharan, R., Panneerselvam, R., (2007c).Studies on germination, seedling vigour, lipid peroxidation and proline metabolism in Catharanthus roseus seedlings under salt stress. South African Journal of Botany 73, 190-195.

Jaleel, C.A., Lakshmanan, G.M.A., Gomathinayagam, M., Panneerselvam, R., 2008a. Triadimefon induced salt stress tolerance in Withania somnifera and its relationship to antioxidant defense system. South African Journal of Botany 74, 126-132.

Jaleel, C.A., Manivannan, P., Lakshmanan, G.M.A., Gomathinayagam, M., Panneerselvam, R., 2008. Alterations in morphological parameters and photosynthetic pigment responses of Catharanthus roseus under soil water deficit stress. Colloids and Surfaces B, Biointerfaces. 61, 298-303.

Jaleel, C.A., Sankar, B., Sridharan, R., Panneerselvam, R., 2008b. Soil salinity alters growth, chlorophyll content, and secondary metabolite accumulation in Catharanthus roseus. Turkish Journal of Biology 32, 79-83.

Jamil, A., Riaz, S., Ashraf, M., Foolad, M.R., 2011.Gene expression profiling of plants under salt stress. Critical Reviews in Plant Sciences 30, 435-458.

Kachhap, S., Chaudhary, A., Singh, S.D., 2015. Response of plant growth promoting rhizobacteria (pgpr) in relation to elevated temperature conditions in groundnut (Arachis hypogaea L.). The Ecoscan 9, 771-778.

Karthikeyan, B., Jaleel, A.C., Azooz, M.M., 2009. Individual and Combined Effects of Azospirillum brasilense and Pseudomonas fluorescens on Biomass Yield and Ajmalicine Production in Catharanthus roseus. Academic Journal of Plant Sciences 2, 69-73.

Karthikeyan, B., Joe, M. M., Islam, R. M. Sa, T., 2012. ACC deaminase containing diazotrophic endophytic bacteria ameliorate salt stress in Catharanthus roseus through reduced ethylene levels and induction of antioxidative defense systems. Symbiosis Doi 10.1007/s13199-0120162-6.

Lambers H, Mougel C, Jaillard B, Hinsinger P., 2009. Plantmicrobe-soil interactions in the rhizosphere, an evolutionary perspective. Plant Soil. 321,83-115

Lauchli, A., Epstein, E., 1990. Plant responses to saline and sodic conditions.In K. K. Tanji (Ed.), Agricultural salinity assessment and management. New York, American Society of Civil Engineers. 113-137.

Lauchli, A., Grattan, S. R., 2007. Plant Growth And Development Under Salinity Stress. In Jenks, M. A., Hasegawa, P. M. and Jain, S. M. (Eds.), Advances in molecular breeding toward drought and salt tolerant crops, Springer Netherlands. 1-32

Lauchli, A., James, R. A., Huang, C. X., McCully, M., Munns, R., 2008. Cell-specific localization of $\mathrm{Na}^{+}$in roots of durum wheat and possible control points for salt exclusion. Plant Cell and Environment 31, 1565-1574.

Leithy, S., Gaballah, M.S., Gomaa, A.M., 2009. Associative impact of bio and organic fertilizers on geranium plants grown under saline conditions. International Journal of Academic Research 1, 17-23.

Lugtenberg, B., Kamilova, F., 2009.Plant growth promoting rhizobacteria. Annual Review of Microbiology 63, 541-556.

Lugtenberg, B.J.J., Dekkers, L., Bloemberg, G.V., 2001. Molecular determinants of rhizosphere colonization by Pseudomanas. Annual Review of Phytopathology 39, 461-490.

Mahmoodzadeh H., 2008. Ultrastructural changes in shoot apical meristem of canola (Brassica napus cv. Symbol) treated with sodium chloride. Pakistan Journal of Biological Sciences 11, 1161-1164.

Mayak, S., Triosh, T., Glick, B.R., 2004. Plant growth promoting bacteria that confer resistance to water stress in tomatoes and peppers. Plant Science 166, 525-530.

Mondal, H.K., Narayanan, R., Kumutha, K., Malarvizhi, P., 
2016. Assessment of phosphorus use efficiency on acid tolerant arbuscular mycorrhizal fungi using radiotracer technique and their plant growth promotion in sorghum with combined inoculation of phosphobacterium and Azospirillum. The Ecoscan 9, 421-429.

Mondal, H.K., Gera, R., Kumar, R., 2017. Alleviation of high abiotic stress in clusterbean using stress-tolerant Rhizobia as multi-trait PGPR. Green Farming 8, 394-398.

Muhammad, Z., Hussain, F., 2010. Vegetative growth performance of five Medicinal plants under $\mathrm{NaCl}$ salt stress. Pakistan Journal of Botany 42, 303-316.

Munns, R., 2003. Comparative physiology of salt and water stress. Plant Cell Environ 25, 239-50.

Munns, R., Termaat, A., 1986. Whole-Plant Responses to Salinity. Functional Plant Biology 13, 143-160.

Munns, R., Tester, M., 2008. Mechanisms of salinity tolerance. Annual Review of Plant Biology 59, 651-681.

Murkute A.A., Sharma, S., Singh, S.K., 2006. Studies on salt stress tolerance of citrus rootstock genotypes with arbuscularmycorrhizal fungi. Horticultural Science 33, 70-76.

Murthy, N.K., Srinivasan, S., Warrier, R.K., 1998. Effect of Azospirillum and Phosphobacterium in improving seed germination and vigour of Amla. Journal of Non Timber Forest Products 6, 34-36.

Nabizadeh E., 2002. Effect of salinity on cumin growth and yield. Iranian Journal of Field Crops Research 1, 20-29.

Najafi, F., Khavari-Nejad, R.A., Ali, M.S., 2010. The effects of salt stress on certain physiological parameters in summer savory (Satureja hortensis L.) plants. Journal of Stress Physiology and Biochemistry 6, 13-21.

Najafian, S., Khoshkhui, M., Tavallali, V., Saharkhiz, M.J., 2009. Effect of salicylic acid and salinity in thyme (Thymus vulgaris L.), investigation on changes in gas exchange, water relations, and membrane stabilization and biomass accumulation. Australian Journal of Basic and Applied Sciences 3, 2620-2626.

Netondo, G.W., Onyango, J.C., Beck, E., 2004. Sorghum and salinity, Gas exchange and chlorophyll fluorescence of sorghum under salt stress. Crop Science 44, 806-811.

Ouyang, B., Yang, T., Li, H., Zhang, L., Zhang, Y., Zhang, J., et al., 2007.Identification of early salt stress response genes into tomato root by suppression subtractive hybridization and microarray analysis. Journal of Experimental Botany 58, 507-520.

Ozturk, A., Unlukara, A., Ipekl, A., Gurbuz, B., 2004. Effect of salt stress and water deficit on plant growth and essential oil content of lemon balm (Melissa officinalis L.). Pakistan Journal of Botany 36, 787-92.

Parida, A.K., Das, A.B., 2005. Salt tolerance and salinity effects on plants, A review. Ecotoxicology and Environmental Safety 60, 324-349.

Patel, B.B., Patel, Bharat.B., Dave, R.S., 2011. Studies on infiltration of saline-alkali soils of several parts of
Mehsana and Patan districts of north Gujarat. Journal of Applied Technology in Environmental Sanitation 1, 87-92.

Paul, D., 2012. Osmotic stress adaptations in rhizobacteria. Journal of Basic Microbiology 52, 1-10.

Pundarikakshudu, K., Patel, J.K., Bodar, M.S., Deans, S.G., 2001. Antibacterial activity of Galega officinalis L. (Goat's Rue). Journal of Ethnopharmacology 77, 111-112.

Queslati, S., Karray-Bouraoui, N., Attia, H., Rabhi, M., Ksouri, R., Lachaal, M., 2010. Physiological and antioxidant responses of Mentha pulegium (Pennyroyal) to salt stress. Acta Physiologiae Plantarum 32, 289-296.

Qureshi, M.I., Israr, M., Abdin, M.Z., Iqbal, M., 2005. Responses of Artemisia annua L. to lead and salt induced oxidative stress. Environmental and Experimental Botany 53, 185-193.

Rabie, G.H, Almadini, A.M., 2005. Role of bioinoculants in development of salt-tolerance of Vicia faba plants under salinity stress. African Journal of Biotechnology 4, 210-222.

Ramezani, E., Sepanlou, M.G., Badi, H.A.N., 2011. The effect of salinity on the growth, morphology and physiology of Echium amoenum Fisch. \& Mey. African Journal of Biotechnology 10, 8765-8773.

Ramin, A.A., 2005. Effects of salinity and temperature on germination and seedling establishment of sweet basil (Ocimum basilicum L.). Journal of Herbs, Spices and Medicinal Plants 11, 81-90.

Rout, N.P., Shaw, B.P., 2005. Salt tolerance in aquatic macrophytes, Ionic relation and interaction. Biologia Plantarum 55, 91-95.

Said-Al Ahl. H.A.H., Omer, E.A., 2011. Medicinal and aromatic plants production under salt stress. $A$ review. Herbapolonica 57, 72-87.

Selvaraj, T., Sumithra, P., 2011. Effect of Glomus aggregatum and plant growth promoting rhizomicroorganisms on growth, nutrition and content of secondary metabolites in Glycyrrhiza glabra L. Indian Journal of Applied \& Pure Biology 26, 283-290.

Serrano, R., Culianz-Macia, F., Moreno, V., 1999.Genetic engineering of salt and drought tolerance with yeast regulatory genes. Scientia Horticulturae 78, 261-269.

Shalan, M.N., Abdel-Latif, T.A.T., Ghadban, E.A. E. El., 2006. Effect of water salinity and some nutritional compounds of the growth and production of sweet marjoram plants (Majorana hortensis L.). Egyptian Journal of Agricultural Research 84, 959.

Sheng, M., Tang, M., Chan, H., Yang, B., Zhang, F., Huang, Y., 2008. Influence of arbuscular mycorrhizae on photosynthesis and water status of maize plants under salt stress. Mycorrhiza 18, 287-296.

Singh, J.S., Pandey, V.C., Singh, D.P., 2011. Efficient soil microorganisms, A new dimension for sustainable agriculture and environmental development. 
Agriculture Ecosystems and Environment 140, 339-353

Sosa, L., Llanes, A., Reinoso, H., Reginato, M., Luna V., 2005. Osmotic and specific ion effect on the germination of Prospis strombulifera. Annals of Botany 96, 261-267.

Srivastava, P., Kumar, R., 2015. Soil salinity, A serious environmental issue and plant growth promoting bacteria as one of the tools for its alleviation. Saudi Journal of Biological Sciences 22, 123-131.

Sun, K., Hunt, K., Hauser, B.A., 2004. Ovule abortion in Arabidopsis triggered by stress. Plant Physiology 135, 2358-2367.

Tabatabaie, S.J., Nazari, J., 2007. Influence of nutrient concentration and $\mathrm{NaCl}$ salinity on growth, photosynthesis and essential oil content of peppermint and lemon verbena. Turkish Journal of Agriculture and Forestry 31, 245-53.

Timperio, A.M., Egidi,M.G., Zolla, L., 2008. Proteomics applied on plant abiotic stresses, role of heat shock proteins(HSP). Journal of Proteomics 71, 391-411.

Vriezen, J.A.C., Bruijn, F.J., Nusslein, K., 2007. Responses of
Rhizobia to desiccation in relation to osmotic stress, oxygen, and temperature. Applied and Environmental Microbiology 73, 3451-3459.

Wang, W., Vinocur, B., Altman, A., 2003. Plant responses to drought, salinity and extreme temperatures, towards genetic engineering for stress tolerance. Planta 218, $1-14$.

Yamane, K., Rahman Md, S., Kawasaki, M., Taniguchi, M., Miyake, H., 2004. Pretreatment with a low concentration of methyl viologen decreases the effects of salt stress on chloroplast ultrastructure in rice leaves (Oryza sativa L.). Plant Production Science 7, 435-441.

Zhu, J.K., 2007. Plant salt stress. eLS. Available from: http:// www.faculty.ucr.edu/ jkzhu/articles/2007/ELS\%20Zhu. pdf

Zuccarini, P., Okurowska, P., 2008. Effects of mycorrhizal colonization and fertilization on growth and photosynthesis of sweet basil under salt stress. Journal of Plant Nutrition 31, 497-513. 